\title{
Identification of effective factors on customer loyalty with mobile industry
}

\author{
Soheila Sardar Donighi ${ }^{\mathrm{a}}$ and Somayeh Davarpanah ${ }^{\mathrm{b}^{*}}$
}

${ }^{a}$ Assist. Prof. \& Faculty Member, Department of Commercial Management, School of Management, Tehran North Branch, Islamic Azad University (IAU), Tehran, Iran

${ }^{b}$ M.Sc. Student, Department of Commercial Management, School of Management, Tehran North Branch, Islamic Azad University (IAU), Tehran, Iran C H R O N I C L E A B S T R A C T

Article history:

Received May 12, 2013

Received in revised format 30 June 2013

Accepted 28 July 2013

Available online

July 302013

Keywords:

American Customer Satisfaction

Model

Customer loyalty

Customer Expectations

Perceived Quality

Perceived Value

Customer Satisfaction

Repurchase Likelihood

Price Tolerance and Customer

Complaint

\begin{abstract}
Customers or clients are counted to be reasons for existence and continuation of life of every organization and, therefore, it is essential to review various aspects of customer satisfaction. Many customers may seem to be satisfied but they may switch to competitor companies for various reasons. Loyal customers constitute a major factor for organizational successes and there are many attempts to create loyal customers. The customer loyalty was defined as commitment of customers to deal with a particular organization or buy given goods repeatedly. During the present research, the researcher engages in the evaluation of factors effective on satisfaction and loyalty of customers and in the study of their interactions, using the famous American Model of Customer Satisfaction. Major variables of such pattern are as follows: customer expectations, perceived quality, perceived value, customer satisfaction, Repurchase Likelihood, Price Tolerance changes and customer complaint. In this study, 384 cell-phone users were randomly selected from different departments of North Tehran Branch of Islamic Azad University. Valuable data were gathered by closed response questionnaire. Afterward we derived eleven correlations between different parameters by using structural equation modeling. Finally, all of suppositions were confirmed by confidence level up to $95 \%$. In addition, the SPSS and XLSTAT PLS software packages are utilized in the process and analysis of data and investigation of study's hypotheses and necessary analyses have been done.
\end{abstract}

(C) 2013 Growing Science Ltd. All rights reserved.

\section{Introduction}

Customer satisfaction has been a major concern and can be a bridge for building loyal customers (Fornell, 1992; Churchill Jr \& Surprenant, 1982; Fornell et al., 1996; Chan et al., 2003; Kotler, P., \& Keller, 2012). Eklöf (2000), for instance, considered European customer satisfaction index panEuropean telecommunication sector report based on the pilot studies 1999. Hsu et al. (2006) presented an application of customer satisfaction study to derive customer knowledge. Hackl et al. (2000) studied customer satisfaction in the Austrian food retail market. Hellier et al. (2003) investigated customer repurchase intention by looking into a general structural equation model. Su

*Corresponding author. +98-912-2995919

E-mail address: somayeh.davarpanah@yahoo.com (S. Davarpanah) 
(2004) concentrated on hotel guest comment cards (GCCs) and customer satisfaction management schemes in Taiwan by implementing content analysis to detect the extent in which each hotel's comment card design corresponded to the identified best practice criteria. Su reported that no single hotel analyzed within the survey sample of the study met all identified best practice criteria for their GCCs. Su recommended that the hotel industry in Taiwan re-examine its approach to evaluat customer satisfaction, with the objective of achieving conformity to all critical best practice criteria identified. Anderson et al. (1994) used a method originally suggested by Carman (1970) to empiricaly investigat customer satisfaction, market share, and profitability in Sweden. Andreassen and Lindestad (1998) performed a survey on customer loyalty and complex services by looking into the impact of corporate image on quality, customer satisfaction and loyalty for customers with varying degrees of service expertise. Aydin and \& Özer (2005) investigated national customer satisfaction indices in the Turkish mobile telephone market. Ball et al. (2004) studied the role of communication and trust in explaining customer loyalty. Beerli et al. (2004) reported that satisfaction together with personal switching costs were antecedents leading directly to customer loyalty, with the former exerting the greatest influence; and perceived quality was a consequence of satisfaction in banking industry. Biggs and Swailes (2006) investigated the relationships, commitment and satisfaction in agency workers and permanent workers. They reported that there were significant correlations within the sample between organizational commitment, being valued and job satisfaction further supported by a hierarchical multiple linear regression. Boulding et al. (1993) presented a dynamic process model of service quality: from expectations to behavioral intentions. Bruhn and Grund (2000) developed theory, development and implementation of national customer satisfaction indices in the Swiss Index of Customer Satisfaction (SWICS). Caruana (2002) considered service loyalty by looking into the effects of service quality and the mediating role of customer satisfaction. Cater and Cater (2009) investigated the relationship-value-based antecedents of customer satisfaction and loyalty in manufacturing. Gerpott et al. (2001) studied the relationship among customer retention, loyalty, and satisfaction in the German mobile cellular telecommunications market. Guo et al. (2004) investigated the relationship between customer loyalty and profitability. Karjaluoto et al. (2002) studied different factors underlying attitude formation towards online banking in Finland. Kristensen et al. (2000) measured customer satisfaction as a key dimension of business performance. They stated that customer satisfaction is an increasingly powerful dimension of business performance and explained empirical evidence that customer satisfaction measures had an impact on business.

Ndubisi (2006) investigated the effect of gender on customer loyalty by looking into a relationship marketing approach. The author aimed to investigate the role of gender in the association of relationship marketing underpinnings with customer loyalty. The results showed that the four underpinnings of relationship marketing were directly associated with customer loyalty.

\section{The proposed model}

The proposed study of this paper measures the effect of quality of services (Zeithaml, 1996) on different issues such as customer satisfaction, customer complaints, etc. and it is performed among a sample of North Tehran branch of Islamic Azad University in city of Tehran, Iran who had some experience on using mobile services in a 8-month period in 2012. The sample size is determined as follows,

$$
n=\frac{N \times z_{\alpha / 2}^{2} \times p \times q}{\varepsilon^{2} \times(N-1)+z_{\alpha / 2}^{2} \times p \times q},
$$

where $N$ is the population size, $p=1-q$ represents the yes/no categories, $z_{\alpha / 2}$ is CDF of normal distribution and finally $\varepsilon$ is the error term. Since we have $p=0.5, z_{\alpha / 2}=1.96$ and $N=4500$, the number of sample size is calculated as $n=384$. In our study, we have distributed 400 questionnaires and managed to collect 384 filled ones. All questions were designed in Likert scale in four different categories. Table 1 demonstrates some of the results of our findings, 
Table 1

The summary of content verification

\begin{tabular}{|c|c|c|c|c|c|}
\hline Component & \# of questions & Cronbach alpha & Dillon-Goldstein's rho & Eigenvalues & Result \\
\hline \multirow{3}{*}{ Customer expectation } & 3 & 0.972 & 0.983 & 2.497 & \multirow{3}{*}{ Acceptable } \\
\hline & & & & 0.071 & \\
\hline & & & & 0.056 & \\
\hline \multirow{3}{*}{ Perceived quality } & 3 & 0.96 & 0.975 & 2.682 & \multirow[t]{3}{*}{ Acceptable } \\
\hline & & & & 0.127 & \\
\hline & & & & 0.082 & \\
\hline \multirow{2}{*}{ Expected values } & 2 & 0.941 & 0.972 & 2.13 & \multirow[t]{2}{*}{ Acceptable } \\
\hline & & & & 0.124 & \\
\hline \multirow{3}{*}{ Customer satisfaction } & 3 & 0.958 & 0.973 & 2.565 & \multirow[t]{3}{*}{ Acceptable } \\
\hline & & & & 0.146 & \\
\hline & & & & 0.065 & \\
\hline \multirow{2}{*}{ Price tolerance } & 2 & 0.986 & 0.993 & 3.865 & \multirow[t]{2}{*}{ Acceptable } \\
\hline & & & & 0.052 & \\
\hline \multirow{2}{*}{ Repurchase likelihood } & 2 & 0.979 & 0.99 & 2.407 & \multirow[t]{2}{*}{ Acceptable } \\
\hline & & & & 0.05 & \\
\hline
\end{tabular}

As we can observe from the results of Table 1, all components can be verified and we can proceed the survey. In addition, the survey has been verified based on different methods and Table 2 summarizes the results of our survey.

Table 2

The summary of validating the questionnaire of our survey

\begin{tabular}{|c|c|c|c|c|c|c|c|c|c|c|c|}
\hline \multirow{2}{*}{ Component } & \multirow{2}{*}{ Symbol } & \multicolumn{7}{|c|}{ Different component validation results } & \multicolumn{3}{|c|}{ Validation } \\
\hline & & PE & PQ & PV & $\mathrm{CS}$ & PT & RL & $\mathrm{CC}$ & Factor & Error & Critical \\
\hline \multirow{3}{*}{$\begin{array}{l}\text { Perceived } \\
\text { expectations }\end{array}$} & PE1 & 0.973 & 0.884 & 0.876 & 0.902 & 0.878 & 0.867 & -0.896 & 0.973 & 0.005 & 202.223 \\
\hline & PE2 & 0.973 & 0.916 & 0.885 & 0.919 & 0.849 & 0.906 & -0.897 & 0.973 & 0.004 & 233.494 \\
\hline & PE3 & 0.98 & 0.918 & 0.905 & 0.911 & 0.863 & 0.918 & -0.922 & 0.98 & 0.002 & 494.5 \\
\hline \multirow{3}{*}{$\begin{array}{l}\text { Perceived } \\
\text { quality }\end{array}$} & PQ1 & 0.878 & 0.968 & 0.917 & 0.905 & 0.86 & 0.871 & -0.882 & 0.968 & 0.003 & 285.796 \\
\hline & PQ2 & 0.904 & 0.959 & 0.889 & 0.899 & 0.816 & 0.891 & -0.894 & 0.959 & 0.004 & 243.242 \\
\hline & PQ3 & 0.908 & 0.962 & 0.943 & 0.944 & 0.914 & 0.953 & -0.892 & 0.962 & 0.003 & 293.653 \\
\hline \multirow{2}{*}{$\begin{array}{l}\text { Perceived } \\
\text { value }\end{array}$} & PV1 & 0.882 & 0.92 & 0.973 & 0.943 & 0.962 & 0.91 & -0.867 & 0.973 & 0.002 & 474.012 \\
\hline & PV2 & 0.893 & 0.935 & 0.971 & 0.93 & 0.912 & 0.965 & -0.91 & 0.971 & 0.003 & 384.425 \\
\hline \multirow{3}{*}{$\begin{array}{l}\text { Customer } \\
\text { satisfaction }\end{array}$} & CS1 & 0.892 & 0.918 & 0.922 & 0.968 & 0.876 & 0.912 & -0.841 & 0.968 & 0.004 & 238.513 \\
\hline & CS2 & 0.894 & 0.911 & 0.909 & 0.954 & 0.878 & 0.927 & -0.906 & 0.954 & 0.004 & 250.235 \\
\hline & $\mathrm{CS} 3$ & 0.904 & 0.918 & 0.946 & 0.964 & 0.929 & 0.905 & -0.872 & 0.964 & 0.004 & 260.207 \\
\hline \multirow{2}{*}{$\begin{array}{l}\text { Price } \\
\text { tolerance }\end{array}$} & PT1 & 0.875 & 0.894 & 0.961 & 0.923 & 0.994 & 0.919 & -0.875 & 0.994 & 0.001 & 1038.698 \\
\hline & $\mathrm{Pt} 2$ & 0.883 & 0.896 & 0.955 & 0.928 & 0.993 & 0.929 & -0.894 & 0.993 & 0.001 & 938.45 \\
\hline \multirow{2}{*}{$\begin{array}{l}\text { Repurchase } \\
\text { likelihood }\end{array}$} & RL1 & 0.915 & 0.932 & 0.95 & 0.935 & 0.922 & 0.991 & -0.933 & 0.991 & 0.001 & 899.962 \\
\hline & RL2 & 0.911 & 0.932 & 0.959 & 0.95 & 0.919 & 0.989 & -0.915 & 0.989 & 0.002 & 655.972 \\
\hline Customer & $\mathrm{CC} 1$ & -0.929 & -0.923 & -0.914 & -0.911 & -0.89 & -0.934 & 1 & 1 & 0 & - \\
\hline \multicolumn{2}{|l|}{ Reliability } & 0.951 & 0.927 & 0.945 & 0.925 & 0.987 & 0.98 & - & \multicolumn{3}{|c|}{ Result: confirmed } \\
\hline
\end{tabular}

The results of Table 2 also verify the questionnaire and we can proceed the survey. The proposed model of this paper considers the following hypotheses,

1. Perceived expectation (PE) influences on perceived quality (PQ), positively.

2. Perceived expectation (PE) influences on perceived value (PV), positively (Söderlund, 1998).

3. Perceived quality (PQ) influences on perceived value (PV), positively (Wang, 2004).

4. Perceived expectation (PE) influences on customer satisfaction (CS), positively.

5. Perceived quality (PQ) influences on customer satisfaction (CS), positively.

6. Perceived value (PV) influences on customer satisfaction (CS), positively(Turel, \& Serenko, 2006).

7. Customer satisfaction (CS) influences on repurchase likelihood (RL), positively.

8. Customer satisfaction (CS) influences on price tolerance (PT), positively due to special features of service provider (Vilares \& Coelho, 2003).

9. Customer satisfaction (CS) influences on customer complaints (CC) (Woodruff et al., 1983).

10. Customer complaints (CC) influences on likelihood of repurchase (LR).

11. Customer complaints (CC) influences on price tolerance (PT), positively due to special features of service provider. 


\subsection{Personal characteristics of the participants}

In our survey, $104(27.1 \%)$ of the participants were male and $280(72.9 \%)$ participants were female students participated. Fig. 1 demonstrates other relevant information associated with this survey.

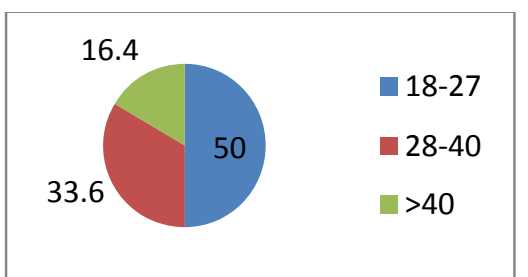

Age

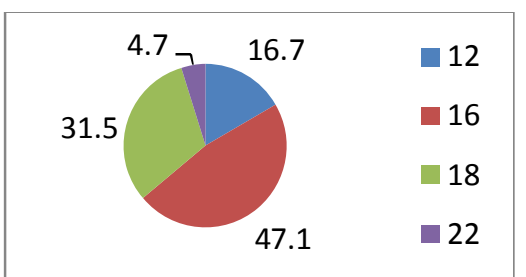

Years of educations

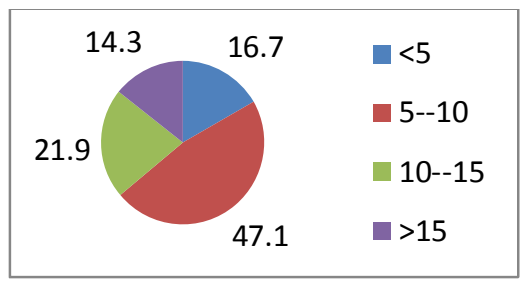

Average income (Million Rials)

Fig. 1. Personal characteristics in terms of percentage

Most participants were using two primary mobile service providers of HAMRAH AVAL with 52.6\% and IranCell with 36.5\%.

Table 3 shows details of our findings on some basic statsitics on the survey.

Table 3

The summary of some basic statsitsics

\begin{tabular}{lcccccccc}
\hline Variable & Number & Mean & $\begin{array}{c}\text { Std. } \\
\text { Dev. }\end{array}$ & Variance & Skewness & kurtosis & \multicolumn{2}{c}{ Deviation } \\
Skewness & kurtosis \\
\hline Customer expectations & 384 & 3.769 & 0.911 & 0.831 & -0.501 & 0.096 & -4.022 & 0.386 \\
Perceived quality & 384 & 3.287 & 0.946 & 0.894 & -0.562 & 0.135 & -4.516 & 0.545 \\
Perceived expectations & 384 & 2.865 & 1.033 & 1.068 & 0.07 & -0.285 & 0.565 & -1.146 \\
Customer satisfaction & 384 & 2.909 & 0.925 & 0.855 & -0.088 & -0.069 & -0.705 & -0.279 \\
Repurchase likelihood & 384 & 3.003 & 1.098 & 1.206 & -0.163 & -0.724 & -1.306 & -2.915 \\
Customer complaints & 384 & 2.294 & 1.189 & 1.414 & 0.651 & -0.394 & 5.224 & -1.586 \\
Price tolerance & 384 & 2.853 & 1.392 & 1.937 & 0.461 & -0.668 & 3.703 & -2.687 \\
\hline
\end{tabular}

In addition, Table 4 demonstrates the summary of our validation survey on all questionnaires.

Table 4

The summary of validating the questionnaire of our survey

\begin{tabular}{|c|c|c|c|c|c|c|c|c|c|c|}
\hline & \multirow{2}{*}{ Cronbach alpha } & \multirow{2}{*}{ Dillon-Goldstein's rho } & \multirow{2}{*}{$\lambda$} & \multicolumn{7}{|c|}{ Correlation ratio } \\
\hline & & & & $\mathrm{PE}$ & PQ & PV & $\mathrm{CS}$ & $\mathrm{CC}$ & PT & RL \\
\hline $\mathrm{PE}$ & 0.972 & 0.983 & 2.497 & 1 & 0.866 & 0.833 & 0.871 & 0.864 & 0.783 & 0.85 \\
\hline PQ & 0.96 & 0.975 & 2.682 & 0.866 & 1 & 0.91 & 0.908 & 0.851 & 0.811 & 0.887 \\
\hline PV & 0.941 & 0.972 & 2.13 & 0.833 & 0.91 & 1 & 0.928 & 0.835 & 0.93 & 0.929 \\
\hline CS & 0.958 & 0.973 & 2.565 & 0.871 & 0.908 & 0.928 & 1 & 0.83 & 0.868 & 0.906 \\
\hline $\mathrm{CC}$ & - & - & - & 0.864 & 0.851 & 0.835 & 0.83 & 1 & 0.792 & 0.873 \\
\hline PT & 0.986 & 0.993 & 3.865 & 0.783 & 0.811 & 0.93 & 0.868 & 0.792 & 1 & 0.865 \\
\hline RL & 0.979 & 0.99 & 2.407 & 0.85 & 0.887 & 0.929 & 0.906 & 0.873 & 0.865 & 1 \\
\hline
\end{tabular}

The results of Table 4 clearly confirm the overall survey in terms of validation. In addition, there are positive and meaningful correlations among different components of the survey, which validates the overall questionnaire.

\section{The results}

In this section, we present the results of our survey on testing various hypotheses of the survey. Fig. 1 demonstrates the results. 


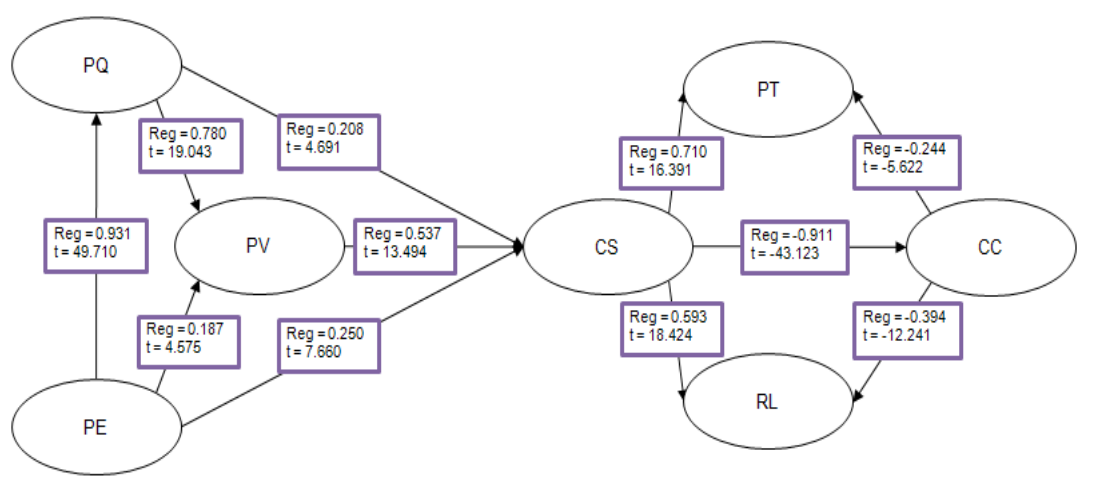

Fig. 1. The summary of the results of our survey

\subsection{The first hypothesis: The effect of PE on $P Q$}

The first hypothesis of this survey examines the effect of perceived expectation on perceived quality. The results of regression analysis yields a positive value of 0.931 with $t$-value $=49.710>19.6$. Since the result of t-student is statistically significance $(\alpha=5 \%)$ we can confirm the first hypothesis and conclude that PE positively influences PQ.

\subsection{The second hypothesis: The effect of PE on PV}

The second hypothesis of this survey examines the effect of perceived expectation on perceived value. The results of regression analysis yields a positive value of 0.187 with $t$-value $=4.575>1.96$. Since the result of t-student is statistically significance $(\alpha=5 \%)$ we can confirm the second hypothesis and conclude that PE positively influences PV.

\subsection{The third hypothesis: The effect of PQ on PV}

The third hypothesis of this survey examines the effect of perceived quality on perceived value. The results of regression analysis yields a positive value of 0.78 with $t$-value $=19.43>1.96$. Since the result of t-student is statistically significance $(\alpha=5 \%)$ we can confirm the third hypothesis and conclude that PQ positively influences PV.

\subsection{The fourth hypothesis: The effect of PE on CS}

The fourth hypothesis of this survey examines the effect of perceived expectation on customer satisfaction. The results of regression analysis yields a positive value of 0.25 with $t$ value $=7.660>1.96$. Since the result of t-student is statistically significance $(\alpha=5 \%)$ we can confirm the fourth hypothesis and conclude that PE positively influences CS.

\subsection{The fifth hypothesis: The effect of $P Q$ on $C S$}

The fifth hypothesis of this survey examines the effect of perceived quality on customer satisfaction. The results of regression analysis yields a positive value of 0.208 with $t$-value $=4.691>1.96$. Since the result of t-student is statistically significance $(\alpha=5 \%)$ we can confirm the fifth hypothesis and conclude that PQ positively influences CS.

\subsection{The sixth hypothesis: The effect of PV on CS}

The sixth hypothesis of this survey examines the effect of perceived value on customer satisfaction. The results of regression analysis yields a positive value of 0.537 with $t$-value $=13.494>1.96$. Since the result of t-student is statistically significance $(\alpha=5 \%)$ we can confirm the sixth hypothesis and conclude that PV positively influences CS. 


\subsection{The seventh hypothesis: The effect of CS on RL}

The seventh hypothesis of this survey examines the effect of customer satisfaction on repurchase likelihood. The results of regression analysis yields a positive value of 0.593 with tvalue $=18.424>1.96$. Since the result of $t$-student is statistically significance $(\alpha=5 \%)$ we can confirm the seventh hypothesis and conclude that CS positively influences RL.

\subsection{The eighth hypothesis: The effect of CS on PT}

The eighth hypothesis of this survey examines the effect of customer satisfaction on price tolerance. The results of regression analysis yields a positive value of 0.710 with $t$-value $=16.391>1.96$. Since the result of t-student is statistically significance $(\alpha=5 \%)$ we can confirm the eighth hypothesis and conclude that CS positively influences PT.

\subsection{The ninth hypothesis: The effect of CS on CC}

The ninth hypothesis of this survey examines the effect of customer satisfaction on customer complaints. The results of regression analysis yields a negative value of -0.911 with $t$-value $=|-43.133|$ $>1.96$. Since the result of t-student is statistically significance $(\alpha=5 \%)$ we can confirm the ninth hypothesis and conclude that CS negatively influences CC.

\subsection{The tenth hypothesis: The effect of CC on RL}

The tenth hypothesis of this survey examines the effect of customer complaints on repurchase likelihood. The results of regression analysis yields a negative value of -0.393 with $t$-value $=|-12.241|$ $>1.96$. Since the result of t-student is statistically significance $(\alpha=5 \%)$ we can confirm the ninth hypothesis and conclude that CS negatively influences RL.

\subsection{The eleventh hypothesis: The effect of CC on PT}

The eleventh hypothesis of this survey examines the effect of customer complaints on price tolerance. The results of regression analysis yields a negative value of -0.244 with $t$-value $=|-5.642|>1.96$. Since the result of t-student is statistically significance $(\alpha=5 \%)$ we can confirm the ninth hypothesis and conclude that CC negatively influences PT.

\section{Conclusion}

In this paper, we have examined the relationship between different components of quality using structural equation modeling. The proposed model of this survey has considered the relationship between perceived quality, perceived expectation, perceived value, customer satisfaction, price tolerance, repurchase likelihood and customer complaints. The results of our study have disclosed that perceived expectation positively influences perceived quality and perceived value. Perceived quality, in turns, influences perceived value, positively. In addition, perceived value influences customer satisfaction and customer satisfaction influences repurchase likelihood and price tolerance, positively. Finally, customer satisfaction negatively influences customer complaints, customer complains, in turn; influences repurchase likelihood and customer complaints influences price tolerance, negatively.

\section{Acknowledgment}

The authors would like to thank anonymous referees for constructive comments on earlier version of this paper. 


\section{References}

Su, A. Y. L. (2004). Customer satisfaction measurement practice in Taiwan hotels. International Journal of Hospitality Management, 23(4), 397-408.

Anderson, E. W., Fornell, C., \& Lehmann, D. R. (1994). Customer satisfaction, market share, and profitability: findings from Sweden. The Journal of Marketing, 53-66.

Andreassen, T. W., \& Lindestad, B. (1998). Customer loyalty and complex services: the impact of corporate image on quality, customer satisfaction and loyalty for customers with varying degrees of service expertise. International Journal of Service Industry Management, 9(1), 7-23.

Aydin, S., \& Özer, G. (2005). National customer satisfaction indices: an implementation in the Turkish mobile telephone market. Marketing Intelligence \& Planning, 23(5), 486-504.

Ball, D., Coelho, P. S., \& Machás, A. (2004). The role of communication and trust in explaining customer loyalty: an extension to the ECSI model. European Journal of Marketing, 38(9/10), 1272-1293.

Beerli, A., Martin, J. D., \& Quintana, A. (2004). A model of customer loyalty in the retail banking market. European Journal of Marketing, 38(1/2), 253-275.

Biggs, D., \& Swailes, S. (2006). Relations, commitment and satisfaction in agency workers and permanent workers. Employee Relations, 28(2), 130-143.

Boulding, W., Kalra, A., Staelin, R., \& Zeithaml, V. A. (1993). A dynamic process model of service quality: from expectations to behavioral intentions. Journal of marketing research, 30(1), 7-27.

Bruhn, M., \& Grund, M. A. (2000). Theory, development and implementation of national customer satisfaction indices: the Swiss Index of Customer Satisfaction (SWICS). Total Quality Management, 11(7), 1017-1028.

Carman, J. M. (1970). Correlates of brand loyalty: some positive results. Journal of Marketing Research, 7, 67-76.

Caruana, A. (2002). Service loyalty: the effects of service quality and the mediating role of customer satisfaction. European Journal of Marketing, 36(7/8), 811-828.

Cater, B., \& Cater, T. (2009). Relationship-value-based antecedents of customer satisfaction and loyalty in manufacturing. Journal of Business \& Industrial Marketing, 24(8), 585-597.

Chan, L. K., Hui, Y. V., Lo, H. P., Siu, K. T., Tso, G. K., \& Wu, M. L. (2003). Consumer satisfaction index: new practice and findings. European Journal of Marketing, 37(5/6), 872-909.

Churchill Jr, G. A., \& Surprenant, C. (1982). An investigation into the determinants of customer satisfaction. Journal of Marketing research, 491-504.

Eklöf, J. A. (2000). European customer satisfaction index pan-European telecommunication sector report based on the pilot studies 1999. European Organization for Quality and European Foundation for Quality Management, Stockholm, Sweden.

Fornell, C. (1992). A national customer satisfaction barometer: the Swedish experience. the Journal of Marketing, 56(1), 6-21.

Fornell, C., Johnson, M. D., Anderson, E. W., Cha, J., \& Bryant, B. E. (1996). The American customer satisfaction index: nature, purpose, and findings. The Journal of Marketing, 60(4), 7-18.

Gerpott, T. J., Rams, W., \& Schindler, A. (2001). Customer retention, loyalty, and satisfaction in the German mobile cellular telecommunications market. Telecommunications policy, 25(4), 249-269.

Guo, C., Kumar, A., \& Jiraporn, P. (2004). Customer satisfaction and profitability: is there a lagged effect?. Journal of Strategic Marketing, 12(3), 129-144.

Hackl, P., Scharitzer, D., \& Zuba, R. (2000). Customer satisfaction in the Austrian food retail market. Total Quality Management, 11(7), 999-1006.

Hagg, G., \& Jonsson, N. (2009). Branding Strategy Among The Swedish Bank - The micro Company Perspective. Master of Science Thesis, University Hogskolan I Halmstad/ Sektionen for Ekonomi och Teknik. 
Hellier, P. K., Geursen, G. M., Carr, R. A., \& Rickard, J. A. (2003). Customer repurchase intention: a general structural equation model. European Journal of Marketing, 37(11/12), 1762-1800.

Hsu, S. H., Chen, W. H., \& Hsueh, J. T. (2006). Application of customer satisfaction study to derive customer knowledge. Total Quality Management and Business Excellence, 17(04), 439-454.

Karjaluoto, H., Mattila, M., \& Pento, T. (2002). Factors underlying attitude formation towards online banking in Finland. International Journal of Bank Marketing, 20(6), 261-272.

Kotler, P., \& Keller, K. L. (2012). Framework for marketing management. Pearson Education India.

Kristensen, K., Martensen, A., \& Gronholdt, L. (2000). Measuring customer satisfaction: a key dimension of business performance. International Journal of Business Performance Management, 2(1), 157-170.

Ndubisi, N. O. (2006). Effect of gender on customer loyalty: a relationship marketing approach. Marketing Intelligence \& Planning, 24(1), 48-61.

Nykamp, D. Q., \& Ringach, D. L. (2002). Full identification of a linear-nonlinear system via crosscorrelation analysis. Journal of Vision, 2(1).

Lovelock, C., \& Wright, L. (1999). Principle of service marketing and management.

Palmer, A., \& Kavanagh, M. (1998). Principles of services marketing. New York: McGraw-Hill.

Palmer, A. (2012). Introduction to marketing: theory and practice. Oxford University Press.

Zeithaml, V. A., Berry, L. L., \& Parasuraman, A. (1991). Understanding customer expectations of service. Sloan Management Review, 32(3), 42.

Peterson, R. A., \& Wilson, W. R. (1992). Measuring customer satisfaction: fact and artifact. Journal of the Academy of Marketing Science, 20(1), 61-71.

Sattari, S. (2007). Application of disconfirmation theory on customer satisfaction determination model in mobile telecommunication. Master Thesis, Continuation Courses Marketing and ecommerce, Luleå University of Technology, pp. 16-42.

Pizam, A., \& Ellis, T. (1999). Customer satisfaction and its measurement in hospitality enterprises. International Journal of Contemporary Hospitality Management, 11(7), 326-339.

Söderlund, M. (1998). Customer satisfaction and its consequences on customer behaviour revisited: The impact of different levels of satisfaction on word-of-mouth, feedback to the supplier and loyalty. International Journal of Service Industry Management, 9(2), 169-188.

Stauss, B., \& Neuhaus, P. (1997). The qualitative satisfaction model. International Journal of Service Industry Management, 8(3), 236-249.

Turel, O., \& Serenko, A. (2006). Satisfaction with mobile services in Canada: An empirical investigation. Telecommunications Policy, 30(5), 314-331.

Vilares, M. J., \& Coelho, P. S. (2003). The employee-customer satisfaction chain in the ECSI model. European Journal of Marketing, 37(11/12), 1703-1722.

Wang, Y., Lo, H. P., Chi, R., \& Yang, Y. (2004). An integrated framework for customer value and customer-relationship-management performance: a customer-based perspective from China. Managing Service Quality, 14(2/3), 169-182.

Woodruff, R. B., Cadotte, E. R., \& Jenkins, R. L. (1983). Modeling consumer satisfaction processes using experience-based norms. Journal of marketing research, 296-304.

Zeithaml, V. A., Berry, L. L., \& Parasuraman, A. (1996). The behavioral consequences of service quality. The Journal of Marketing, 31-46. 